\title{
LEHET-E ÖSSZEFÜGGÉS AZ NLP ELŐFELTEVÉSEI ÉS A SZUBJEKTÍV JÓLLÉT KÖZÖTT?
}

Szerzők:

Karsai Xénia

Debreceni Egyetem

Első szerző e-mail címe:

karsaixenia@gmail.com
Lektorok:

Csukonyi Csilla

Debreceni Egyetem

Körmendi Attila

Debreceni Egyetem

Mezö Ferenc

Eszterházy Károly Egyetem

Koncz István

PEME

Karsai, Xénia (2017): Lehet-e összefüggés az NLP előfeltevései és a szubjektív jóllét között? Különleges Bánásmód, III. évf. 2017/3. szám, 79-86. DOI 10.18458/KB.2017.3.79

\begin{abstract}
Absztrakt
A bemutatásra kerülő vizsgálat arra a kérdésre keresi a választ, hogy a neurolingvisztikus programozás (NLP) előfeltevéseinek elfogadása összefügghet-e a szubjektív jólléttel, a pszichológiai ellenállóképességgel és az asszertív viselkedéssel. Az eredmények alátámasztják a feltételezést, miszerint az előfeltevésekkel való egyetértés olyan gondolkodásmódot képvisel, amely pozitívan korrelál a szubjektív jóllét és a pszichológiai ellenállóképesség értékeivel. Ugyanakkor az asszertív viselkedéssel való összefüggés nem nyert alátámasztást, ami az elméletben elfogadott elvek és azok gyakorlatba való átültetése közötti inkonzisztenciára utalhat.
\end{abstract}

Kulcsszavak: szubjektív jóllét, pszichológiai ellenállóképesség, asszertív viselkedés, neurolingvisztikus programozás

Diszciplína: pszichológia

\section{Abstract}

This study investigates the relationship between the acceptance of the presuppositions of neurolinguistic programming (NLP) and the level of subjective well-being (SWB), psychological immunity and assertive communication. The results provide evidence that acceptance of the presuppositions represent a way of thinking that is positively associated with SWB and it is also positively related to psychological immunity. However no association was found between the acceptance of the presuppositions and assertive behaviour which may suggest that there is a gap between conceptual acceptance and its practical realisation.

Keywords: subjective well-being, psychological immunity, assertive behaviour, neurolinguistic programming

Disciplines: psychology 
Számos tanulmány foglalkozik a szubjektív jóllét elméleti megközelítéseivel és modelljeivel, akárcsak az azt meghatározó tényezők, valamint a lehetséges okok és következmények leírásával (Bradburn, 1969; Diener, 1984; Headey and Wearing, 1990; Dodge, Daly, Huyton and Sanders, 2012; Durayappah, 2011). A legtöbb kutató egyetért abban, hogy a szubjektív jóllét szintje időben viszonylag állandónak tekinthető, ami a figyelmet a dinamikus egyensúly elméletben készletekként leírt változók feltárása felé fordítja (Headey and Wearing, 1990). A vizsgálatok egyik iránya a különböző szociális és demográfiai tényezők hatását célozza, mint pl. életkor, nem, családi állapot, társadalmi és gazdasági helyzet (Haring, Stock and Okun, 1984; Diener, Sandvik, Seidlitz and Diener, 1993). Másik kutatási irányt képvisel a személyiséghez füződő tényezők összefüggéseinek elemzése, pl. személyes törekvések, értékrend, karaktererősség, Big 5 (Emmons, 1986; Sagiv and Schwartz, 2000; Emmons and Diener, 1985; Park, Peterson and Seligman, 2004; Hayes and Joseph, 2003). Ehhez a második irányhoz kapcsolódik a most bemutatásra kerülő kutatás, amely a személy gondolkodásmódja, pontosabban egy meghatározott gondolatrendszerrel való egyetértése és a szubjektív jóllét közötti összefüggést vizsgálja.

\section{AZ NLP ELŐFELTEVÉSEI}

A neurolingvisztikus programozás (NLP) technikák és gyakorlatok széles körét foglalja magába, amelyek a kommunikáció hatékonyságának növelésére és a személyes fejlődésre fókuszálnak. A gyakorlatok megalkotása kivételes képességű személyek modellezése alapján történt, azt állítva, hogy a gyakorlatok használatával bárki szert tehet ezekre a képességekre, és tartós változást érhet el az életében. Az empirikus bizonyítékokat tekintve találkozhatunk az NLP módszereit alátámasztó és azokat megcáfoló eredményekkel egyaránt (Tosey and Mathinson, 2003; Witkowski, 2010). Jelen kutatás szempontjából azonban kizárólag az a filozófia érdekes, ami az NLP technikák sikeres alkalmazhatóságának alapját képezi. Az előfeltevések alkotják az NLP alapgondolatait, központi elveit, hitvallását. A kívánt képességek megszerzéséhez vezető út kezdőpontját jelentik, ugyanakkor nem bizonyított, hogy igazak vagy univerzálisak lennének. Úgy lehetne meghatározni, hogy segédeszközként szolgálnak az emberek számára a gyakorlatokban foglalt gondolkodásmód és újfajta nézőpont elsajátításához. Ahhoz, hogy megtörténjen az attitüdök és a viselkedésmód változása, igaznak kell feltételezni az előfeltevéseket, és ennek megfelelően cselekedni.

Eltekintve a gyakorlati megfontolásoktól és az NLP-vel való összefüggéseitől, az előfeltevéseket kezelhetjük úgy, mint egy életfilozófiát alkotó elvek készletét. Meghatározott értékrendet képviselnek, melyeket Schwartz (1992) motivációs értékelméletének következő elemeivel hozhatunk kapcsolatba: önvezérlés, stimuláció, egyetemesség, jóakarat, teljesítmény. Jelen vizsgálat annak feltárására irányul, hogy azok a személyek, akik az előfeltevések által megjelenített értékrendet nagyobb mértékben tartják megegyezőnek a saját értékeikkel, magasabb szubjektív jóllétröl számolnak-e be, függetlenül a konzisztencia okától. Előfordulhat, hogy valaki személyes jellemzői, vagy korábbi tapasztalatai hatására ért egyet az előfeltevésekkel. Az összefüggés vizsgálata során nem volt feltétel az NLP-ben való jártasság, és az előfeltevések az NLP-re való bármilyen utalás nélkül kerültek bemutatásra.

Az előfeltevések tartalmi és szerkezeti jellemzői azt a feltételezést is megengedik, hogy kapcsolatban állhatnak a változásokkal és a nehézségekkel való megküzdéssel. Ez azt jelentheti, hogy az előfeltevésekben foglalt elvek elfogadásának mértéke pozitívan korrelál a személy pszichológiai ellenállóképességével (Szilágyi és mtsai, 2014). A vizsgálat során ennek az összefüggésnek a tesztelése is megtörtént.

Noha jelen kutatásban az előfeltevések vizsgálata az NLP technikákra, és összességében az NLP-re való utalás nélkül folyt, kézenfekvőnek tünt kiterjeszteni a vizsgálódás körét a gyakorlati megfontolásokra. Ezen a ponton az előfeltevések viselkedésben való megjelenése tünik érdekesnek. Az lenne elvárható, hogy az előfeltevések elfogadása kognitív alapot 
képez az asszertivitás számára, azaz a kihívások magabiztos kezeléséhez és a problémák lehető legjobb, mások által is elfogadható módon történő megoldásához (Bíró és Csukonyi, 2005). Ez ugyancsak magába foglalja a kitüzött célok mások jogainak megsértése nélküli elérését és a gondolatok, valamint az érzelmek társas elöírások mentén történő kifejezését (Peneva and Mavrodiev, 2013).

\section{MÓDSZER}

A vizsgálatban arra a kérdésre kerestük a választ, hogy bármilyen okból történjen is, az NLP előfeltevéseivel való egyetértés okoz-e mérhető különbséget a szubjektív jóllét, a pszichológiai ellenállóképesség és a kommunikáció hatékonyságának vonatkozásában. A hipotézisek tesztelésére online kérdőívet állítottunk össze, amely négy részből állt:

1) saját összeállítású kérdéssor az NLP előfeltevéseivel való egyetértés mérésére

2) Életelégedettség Skála (SWLS)

3) Pszichológiai Immunrendszer Felmérés (PISI)

4) Rathus-féle Asszertivitás Kérdőív

A kérdőív megszerkesztéséhez az onlinekerdoiv.hu programját használtuk, és az ott biztosított felületen keresztül osztottuk meg a kérdöívet közösségi oldalakon, illetve e-mail formájában.

\section{Minta}

94 résztvevő töltötte ki az online kérdőívet. A nemi eloszlás a következő volt: 74 nő (79\%) és 20 férfi (21\%). Az adatgyüjtés mintegy két hétig folyt, és névtelenül történt. A kérdőív elején a résztvevőket tájékoztattuk a vizsgálat körülményeiröl és az adatelemzés módjáról.

\section{Eszközök}

Az NLP elöfeltevéseivel való egyetértés Mivel az NLP soha sem kívánt elméletként megjelenni, az előfeltevéseknek nincs tudományos igazolásuk és az állományuk sem rögzített. Számuk és pontos megfogalmazásuk kis mértékben eltérő lehet a különböző szerzőknél, ez azonban nem érinti lényegüket és tartalmi vázukat. Számos megközelítés összehasonlító tanulmányozása alapján az elemzés végül öt felsorolás felhasználására szükült. (Andreas and Faulkner, 2012; Dotz, 2014; Alder, 2002; O’Connor, 2001; Stenger, 2013). A közös elemek kiszürése és a felsorolások egyesítése 14 elvből álló készletet eredményezett, az alábbiak szerint:

1. A világ nem objektíven olyan, mint amilyennek hisszük. Az embereket meggyőződéseik és érzelmeik befolyásolják abban, hogy milyen képet alakítanak ki a világ jelenségeiről.

2. A múlt eseményein nem tudunk változtatni, de azon a hozzáálláson igen, ahogy ezeket felidézzük. Ily módon csökkenteni lehet a bántó emlékek kellemetlen hatását, és gazdagíthatjuk a kellemes emlékeket.

3. Ha valaki meg tud tenni valamit, akkor az bárki számára megtanulható, tehát érdemes próbálkozni.

4. Mindannyiunkban megvan a lehetőség, hogy belső erőforrásainkat tehetséggé fejlesszük, és nagyszerü eredményeket érjünk el.

5. Ha nem sikerül elérni egy célt, az nem jelent kudarcot, csupán visszajelzés arról, hogy az adott helyzetben más viselkedés esetleg eredményesebb lehet. 
6. Szeretem, ha minél több választási lehetőségem van egy helyzetben, mert így nagyobb az esélye annak, hogy valóban megtalálom a számomra legmegfelelőbb megoldást.

7. A képzelet éppúgy befolyásolja céljaink elérését, mint megtörtént élményeink, megszerzett ismereteink: ha elég élénken el tudjuk képzelni, mit szeretnénk, az könnyebben megvalósul.

8. Viselkedésünk, gesztusaink, arcunk akkor is pontosan árulkodik rólunk, gondolatainkról, érzéseinkről, ha nem beszélünk. Így tulajdonképpen mindig kommunikálunk.

9. A kommunikáció azt jelenti, amit eredményezett. Ha a közlés nem a szándékomnak megfelelő hatást vált ki a partnerből, az jelezheti azt is, hogy nem elég világosan vagy nem a megfelelő módon fejeztem ki gondolataimat. Van lehetőségem ezen változtatni, és elősegíteni a pontosabb értelmezést.

10. Az ember tökéletesen müködik, ami leírható azzal a folyamattal, hogy gondolataink, cselekedeteink, érzéseink következetesen meghatározott eredményt hoznak létre.

11. A helyzet pontosabb elemzésével minden viselkedés mögött felfedezhető valami pozitív szándék.

12. Mindig a legjobbat választjuk. Az adott helyzetben és pillanatban a lehető legjobb döntést hozzuk meg, amit személyes történetünk, saját tapasztalataink, választási lehetőségeink lehetővé tesznek.

13. Cselekedeteink és testi megnyilvánulásaink, valamint gondolataink és érzéseink szorosan összefüggnek. Ha változtatunk testi reakcióinkon, viselkedésünkön, akkor gondolataink, érzéseink is megváltoznak.

14. Ha nem müködik, amit csinálok, akkor kipróbálok valami újat. Ha mindig ugyanazt teszem, akkor az eredmény is ugyanaz marad.

Ezt követően minden állításhoz hozzárendelésre került tartalmi ellenpólusuk, ami révén így 14 ellentétes gondolatpár jött létre. A válaszadóknak minden egyes gondolatpár esetében azt a tagot kellet megjelölniük, amelyik jobban tükrözi saját értékrendjüket és meggyőződéseiket. Az előfeltevésekkel való egyetértés mértékét az mutatja meg, hogy hány esetben választották az előfeltevéseket támogató tagot, tehát a lehetséges pontszámok 0 és 14 közötti értéket vehettek fel.

Szubjektiv jóllét A globális jóllét mérése az Életelégedettség Skála használatával történt (SWLS; Diener, Emmons, Larsen and Griffin, 1985). A skála öt állítást tartalmaz, az egyes tételek értékelése 1 (egyáltalán nem értek egyet) és 7 (teljes mértékben egyetértek) közötti pontszámmal lehetséges.

Pszichológiai ellenállóképesség A Pszichológiai Immunrendszer Felmérés (PISI; Oláh, 1996, 2004) 80 tételből áll, amelyek 16 faktort mérnek (pozitív gondolkodás, kontroll érzés, koherencia érzés, öntisztelet, növekedés érzés, kihívás, társas monitorozás, leleményesség, énhatékonyság, társas mobilizálás, szociális alkotóképesség, szinkronképesség, kitartás, impulzuskontroll, érzelmi kontroll, ingerlékenység gátlás). A tételeket 1-től (alig vagy nem jellemző) 4-ig (teljes mértékben jellemző) terjedő skálán lehet értékelni.

Asszertiv viselkedés A Rathus-féle Asszertivitás Kérdöív (RAS; Rathus, 1973) 30 tételt tartalmaz, melyek +3 (nagyon jellemzö) és -3 (teljesen idegen tőlem) közötti értékeket vehetnek fel.

\section{Eljárás}

A fent felsorolt eszközöket az ismertetéssel egyező sorrendben töltötték ki a résztvevők. Az adatok elemzése az R statisztikai program használatával történt. 


\section{Eredmények}

Az alkalmazandó eljárások meghatározásához a változók normalitásvizsgálata elvégzésre került. Ennek eredménye azt mutatta, hogy az előfeltevésekkel való egyetértés és a szubjektív jóllét esetében a minta nem normális eloszlású $(\mathrm{p}<0,05)$, míg a másik két változó (pszichológiai ellenállóképesség, asszertív viselkedés) normális eloszlásúnak bizonyult $(\mathrm{p}>0,05)$. A korrelációk vizsgálatára ennek megfelelően nemparaméteres eljárásokat alkalmaztunk. A változók leíró statisztikáját és az összefüggésekre vonatkozó eredményeket az alábbiakban ismertetjük.

Az NLP elöfeltevéseivel való egyetértés A válaszadók magas pontszámokkal értékelték egyetértésüket, a minta átlaga 10,74 $(\mathrm{SD}=1,76)$. A nemi különbségeket független mintás Wilcoxon próbával teszteltem, és szignifikánsnak bizonyultak $(\mathrm{p}<0,01)$, az átlag férfiaknál 9,85 $(\mathrm{SD}=1,66)$, nőknél pedig 10,98 $(\mathrm{SD}=1,72)$. Az 1. táblázat foglalja össze az egyes elvekre vonatkozóan az elfogadások és az elutasítások számát.

\section{1. táblázat: Az NLP elöfeltevéseinek elfogadása}

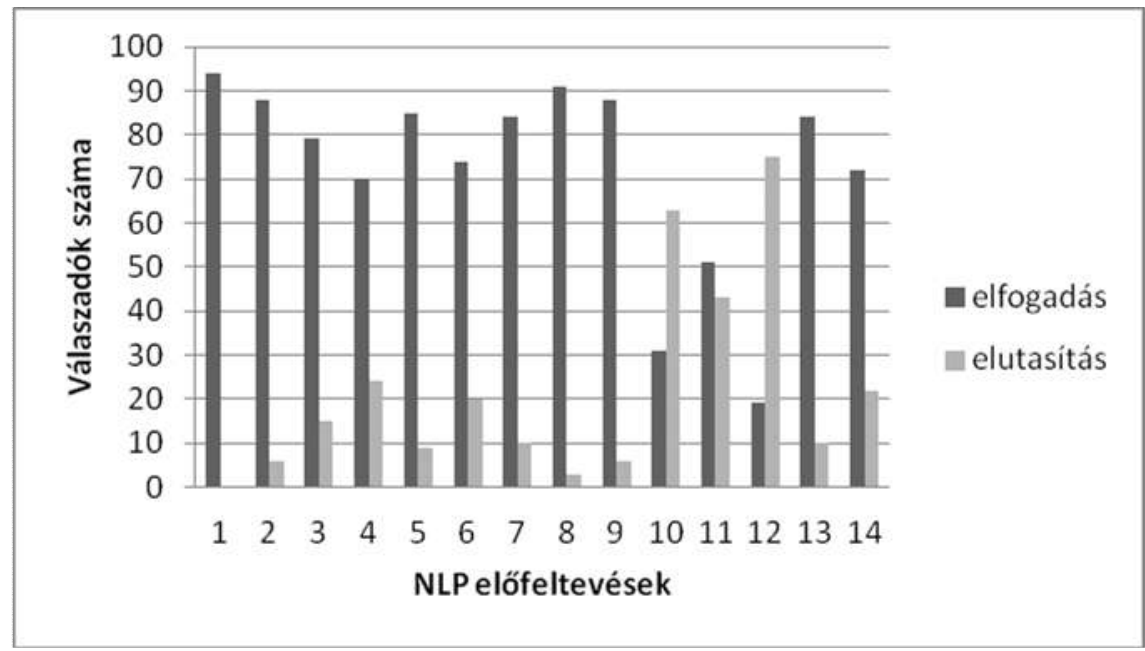

A legtöbb esetben az elfogadás meghaladja az elutasítások számát, két elvet kivéve (Az ember tökéletesen müködik; Mindig a legjobbat választjuk). Ezeken kívül még egy esetben kiemelkedően magas az elutasítások aránya (Minden viselkedés mögött felfedezhető valami pozitív szándék).

Szubjektív jóllét Az SWLS pontok átlaga 23,59 ( $\mathrm{SD}=6,45)$ és itt nem jelentkeztek szignifikáns nemi különbségek $(M=25,35 ; \mathrm{SD}=6,75$ férfiaknál és $\mathrm{M}=23,12 ; \mathrm{SD}=6,32$ nőknél; $\mathrm{p}>0,05)$. A szubjektív jóllét szintje és az elöfeltevések elfogadásának mértéke közötti összefüggés vizsgálatára Spearman-féle rangkorrelációt futtattunk le, ami alapján a feltételezett pozitív korreláció szignifikánsnak bizonyult ( $r h o=0,406 ; p<0,01)$. Az egyetértés vizsgálatánál tapasztalt szignifikáns nemi különbségeket ezek alapján úgy értelmezhetjük, hogy férfiak esetében a szubjektív jóllét szintje alacsonyabb számú előfeltevés elfogadásával függ össze.

Pszichológiai ellenállóképesség A PISI teszt eredményeinek átlaga 228,65 ( $\mathrm{SD}=32,29)$, szignifikáns nemi különbségek ebben az esetben sem mutatkoztak $(\mathrm{M}=234,5 ; \mathrm{SD}=31,11$ férfiaknál és $\mathrm{M}=227,07 ; \mathrm{SD}=32,62$ nőknél). A PISI teszt pontszámai és az előfeltevésekkel való egyetértés mértéke között feltételezett összefüggés nem tekinthető kiemelkedően erőteljesnek, de szignifikanciája alátámasztást nyert $(\mathrm{rho}=0,298 ; \mathrm{p}<0,01)$. A 2. táblázat a PISI alskálákra vonatkozó részletes eredményeket mutatja be. 
2. táblázat: A PISI alskálák és az elöfeltevések elfogadásának összefüggései

\begin{tabular}{|c|c|c|c|c|c|c|c|}
\hline \multirow[t]{2}{*}{ PISI alskálák } & \multirow[t]{2}{*}{ Standard átlag } & \multicolumn{3}{|c|}{ Minta átlag } & \multicolumn{3}{|c|}{$\begin{array}{c}\text { Kapcsolat az elöfeltevésekkel } \\
\text { (Spearman-féle rho) }\end{array}$} \\
\hline & & összes & nők & férfiak & összes & nők & férfiak \\
\hline Pozitív gondolkodás & 14,3 & 14,51 & 14,54 & 14,4 & 0,39 & 0,391 & 0,595 \\
\hline Kontroll érzés & 13,9 & 13,69 & 13,59 & 14,05 & $0,057^{*}$ & $0,049 *$ & $0,109^{*}$ \\
\hline Koherencia érzés & 16 & 16,01 & 15,93 & 16,3 & 0,307 & 0,268 & 0,531 \\
\hline Öntisztelet & 13,6 & 14,52 & 14,32 & 15,25 & 0,278 & 0,255 & 0,585 \\
\hline Növekedés & 16,5 & 15,83 & 15,93 & 15,45 & 0,256 & $0,172 *$ & 0,543 \\
\hline Kihívás & 14 & 14,38 & 14,23 & 14,95 & 0,252 & 0,292 & $0,256^{*}$ \\
\hline Társas monitorozás & 13,8 & 13,97 & 13,91 & 14,2 & $0,116^{*}$ & $0,082 *$ & $0,272^{*}$ \\
\hline Leleményesség & 13,1 & 14,21 & 13,74 & 15,95 & $0,024 *$ & $0,066^{*}$ & $0,194^{*}$ \\
\hline Énhatékonyság & 14,7 & 14,55 & 14,41 & 15,1 & $0,154^{*}$ & $0,128^{*}$ & 0,403 \\
\hline Társas mobilitás & 13,4 & 13,88 & 13,61 & 14,9 & $0,16^{*}$ & 0,284 & $0,079^{*}$ \\
\hline Szinkronképesség & 12,7 & 13,35 & 13,05 & 14,45 & 0,25 & 0,229 & $0,397^{*}$ \\
\hline Szociális alkotókép. & 14,8 & 14,45 & 14,42 & 14,55 & $0,049 *$ & $0,079 *$ & $0,228^{*}$ \\
\hline Kitartás & 17,6 & 15,85 & 15,08 & 16,05 & $0,067 *$ & $0,044^{*}$ & $0,261^{*}$ \\
\hline Impulzus kontroll & 15 & 14,5 & 14,32 & 15,15 & $0,148 *$ & $0,101^{*}$ & 0,583 \\
\hline Érzelmi kontroll & 13,8 & 12,55 & 12,73 & 11,9 & 0,367 & 0,304 & 0,55 \\
\hline Ingerlékenység gátl. & 13,9 & 12,38 & 12,53 & 11,85 & 0,219 & $0,159 *$ & $0,282 *$ \\
\hline
\end{tabular}

* p >0,05; a korreláció nem szignifikáns

Asszertiv viselkedés RAS kérdőív mintaátlaga 12,59 ( $\mathrm{SD}=21,82)$, szignifikáns nemi különbségek nélkül $(\mathrm{M}=15,7 ; \mathrm{SD}=23,43$ férfiaknál és $\mathrm{M}=11,74 ; \mathrm{SD}=21,45$ nőknél). Az elvárásokkal ellentétben nem igazolódott pozitív összefüggés az asszertív viselkedés és az előfeltevések elfogadásának mértéke között, a két változó függetlenek bizonyult $(p>0,05)$.

\section{Megvitatás}

A bemutatott vizsgálat arra a kérdésre kereste a választ, hogy egy bizonyos gondolatrendszerrel való egyetértés, egész pontosan a neurolingvisztikus programozás (NLP) előfeltevéseinek elfogadása kapcsolatba hozható-e a szubjektív jóllét szintjével, a pszichológiai ellenállóképességgel és az asszertív viselkedéssel. A feltételezésekkel összhangban azok a személyek, akiknél az elöfeltevések által képviselt értékek és saját értékrend nagyobb mértékben megegyezik, a szubjektív jóllét magasabb szintjeiről számoltak be.

$\mathrm{Az}$ eredmények igazolják a pszichológiai ellenállóképesség felmérésének értékei és az elöfeltevések elfogadásának mértéke között feltételezett pozitív korrelációt is. Az előfeltevések olyan meggyőződéseket fogalmaznak meg, amelyek optimizmust, pozitív gondolkodást tükröznek, a kihívások vállalására és mások tiszteletben tartására ösztönöznek. Ez nyomon követhető a PISI teszt bizonyos alskáláival való erőteljesebb összefüggésben.

Ugyanakkor, a várakozással ellentétben, nem nyert alátámasztást az előfeltevések elfogadása és az asszertív viselkedés közötti összefüggés. Ez arra enged következtetni, hogy inkonzisztencia tapasztalható az elvek elfogadása és gyakorlatba való átültetése között. Az elfogadás oldaláról közelítve egy lehetséges magyarázatot jelenthet az, hogy az emberek hajlamosak - a nélkül, hogy valóban azonosulnának ezekkel az értékekkel - olyan elveket elfogadni és hangsúlyozni, amelyeket társas környezetük fontosnak tart (Szilágyi és mtsai, 
2010). A gyakorlatba való transzformálás folyamatát illetően a magyarázat kapcsolatba hozható az önmeghatározás elméletével (Ryan and Deci, 2000): ahhoz, hogy a gondolkodás önmeghatározott cselekvésekben tükröződjék a motiváció és a kontroll magasabb fokú internalizációja szükséges (Csukonyi, 2002). Az eredmények további magyarázatára szolgál Crick és Dodge (1996) szociális információfeldolgozási modellje. Ez alapján az előfeltevések viselkedéses válaszban történő megjelenése akkor valósulhat meg, ha a helyzet értelmezésének és a válaszkonstruálásnak a szakaszában az előfeltevések nem interferálnak további elöfeltevésekkel vagy korai életévekben rögzült maladaptív sémákkal (Körmendi és Szklenárik, 2012; Körmendi és Pataky, 2011).

\section{Korlátozások}

A tanulmány gyakorlati korlátjaként lehetne megemlíteni a mintaválasztással kapcsolatban felmerülő problémákat, ami egyrészt a mintanagyságra vonatkozik, másrészt a minta reprezentativitására.

\section{KONKLÚZIÓK}

Összességében a vizsgálat eredményei demonstrálják a szubjektív jóllét és az NLP előfeltevéseinek elfogadása közötti pozitív kapcsolatot. Ezen az alapon elindulva érdemes folytatni a kutatásokat, különösen a viselkedésbeli aspektusokat és az inkonzisztencia feloldási lehetőségeit illetően. A bemutatott vizsgálati elrendezés nem tartalmazta feltételként az NLP-ben való jártasságot vagy bármilyen korábbi tapasztalat meglétét az NLP technikáival kapcsolatban, ezek bevonása egy újabb lehetséges irányt jelenthet a további kutatások számára.

\section{IRODALOM}

Alder, H. (2002): Handbook of NLP: A Manual for Professional Communicators. Burlington, VT: Gower.

Andreas, S., Faulkner, C. (2012): NLP - A változás te magad légy! Libri, Budapest.

Bíró G. és Csukonyi Cs. (2005): Az asszertivitás és a kábítószerezés kapcsolata a középiskolások körében. In: Münnich Á. (szerk.) A mentális egészséget és egészségmegtartást befolyásoló tényezők. (207-227). Didakt Kiadó, Debrecen

Bradburn, N. (1969): The structure of psychological well-being. Chicago: Aldine.

Crick, N.R., Dodge, K.A. (1996): Social information-processing mechanisms in reactive and proactive aggression. Child Development, 67, 993-1002.

Csukonyi Cs. (2002): A motiváció alapelvei. In: Münnich Á. (szerk.) A jövő vezetőinek jelene: Az egyetemi diákság karrierépitési komponenseinek lélektani háttere. (15-31). ELTE Eötvös Kiadó, Budapest

Diener, E. (1984): Subjective well-being. Psychological Bulletin, 95, 542-575.

Diener, E., Emmons, R.A., Larsen, R.J., Griffin, S. (1985): The Satisfaction With Life Scale, Journal of Personal Assessment, 49, 71-75.

Diener, E., Sandvik, E., Seidlitz, L. and Diener, M. (1993): The relationship between income and subjective well-being: Realtive or absolute? Social Indicators Research, 28, 195-223.

Dodge, R., Daly, A.P., Huyton, J., Sanders, L.D. (2012): The challenge of defining wellbeing. International Journal of Wellbeing, 2, 222-235.

Dotz, T. (2014): The Top 13 Original Major Presuppositions of NLP Defined. NLP Comprehensive. letöltve: 2015.03.05. http://www.nlpco.com/2014/10/presuppositions-ofnlp/\#axzz3UTiWKR8g

Durayappah, A. (2011): The 3P model: A general theory of subjective well-being. Journal of Happiness Studies, 12, 681-716. 
Emmons, R.A. (1986): Personal strivings: An approach to personality and subjective wellbeing. Journal of Personality and Social Psychology, 51, 1058-1068.

Emmons, R.A., Diener, E. (1985): Personality correlates of subjective well-being. Personality and Social Psychology Bulletin, 11, 89-97.

Haring, M.J., Stock, W.A., Okun, M.A. (1984): A research synthesis of gender and social class as correlates of subjective well-being. Human Relations, 37, 645-657.

Hayes, N., Joseph, S. (2003): Big 5 correlates of three measures of subjective well-being. Personality and Individual Differences, 34, 723-727.

Headey, B.W., Wearing, A.J. (1991): Subjective well-being: a stocks and flows framework. In: Strack, F., Argyle, M, Schwartz, N. (szerk.): Subjective wellbeing - An interdisciplinary perspective. Oxford: Pergamon Press. 49-76.

Körmendi, A., Pataky, N. (2011): Agresszió és szociális információfeldolgozás az iskolában. Új Pedagógiai Szemle, 1-5, 50-55.

Körmendi, A., Szklenárik, P. (2012): Az iskolai zaklatás. Debreceni Egyetemi kiadó, Debrecen.

O'Connor, J. (2001): The NLP Workbook: A Practical Guide to Achieving the Results You Want. London: Element.

Oláh A. (1996): Psychological immune system: An integrated structure of coping potential dimensions. Paper presented at the 9th conference of the European Health Psychology Society, Bergen, Norway, 1996.

Oláh A. (2000): Health protective and health promoting resources in personality: A framework for the measurement of the psychological immune system. Paper presented at the First International Positive Psychology Summit, Washington DC, 2002.

Park, N., Peterson, C., Seligman, M.E.P. (2004): Strength of character and well-being. Journal of Social and Clinical Psychology, 23, 603-619.

Peneva, I., Mavrodiev, S. (2013): A historical approach to assertiveness. Psychological Thought, 6, 3-26.

Rathus, S.A: (1973): A 30-item schedule for assessing assertive behavior. Behavior Therapy, 4, 398-406.

Ryan, R. M., Deci, E.L. (2000): Self-determination theory and the facilitation of intrinsic motivation, social development and well-being. American Psychology, 55 (1), 68-78.

Sagiv, L., Schwartz S.H. (2000): Value priorities and subjective well-being: direct relations and congruity affects. European Journal of Social Psychology, 30 (2), 177-198.

Schwartz, S. H. (1992): Universals in the content and structures of values: Theoretical advances and empirical test sin 20 countries. Advances in Experimental Social Psychology, $25,1-65$.

Stenger Gy. (2013): A változás müvészete. NLP alapok alapja. NLP Akadémia, Budapest.

Szilágyi Zs., Csukonyi Cs., Sótér A., Hornyák B. (2014): A mentális állóképességvizsgálatok bevezetésének lépései a Magyar Honvédség állományában (2006-2009). Hadtudományi Szemle, (1), 158-178.

Szilágyi, Zs., Kopcsó, I., Csukonyi, Cs. and Németh, A. (2010): Comparative analysis of stress and coping features of Hungarian soldiers serving in missions. AARMS, 1, (9), pp. 87-105.

Tosey, P., Mathinson, J. (2003): Neuro-linguistic programming and learning theory: A response. Curriculum Journal, 14, 361-378.

Witkowski, T. (2010): Thirty-Five Years of Research on Neuro-Linguistic Programming. NLP Research Data Base. State of the Art or Pseudoscientific Decoration? Polish Psychological Bulletin, 41, (2), 58-66. 